\title{
Dlaczego w relacji Mateusza (21,1-11) Jezus wjeżdżał do Jerozolimy na dwóch osłach? Część 1: Referent drugiego zaimka aủiũv w Mt 21,7
}

Why Did Jesus Enter Jerusalem Riding on Two Donkeys in Matthew's Account (21:1-11)? Part 1: The Referent for the Second Pronoun aútw̃v in Mt 21:7

\author{
KS. ADAM KUBIŚ \\ Instytut Nauk Biblijnych, Katolicki Uniwersytet Lubelski Jana Pawła II \\ e-mail: akubis@gmail.com \\ ORCID: 0000-0003-4961-2254
}

\begin{abstract}
Summary: The article deals with one of the problematic issues found in the Matthean entry narrative (21:1-11), namely identifying the appropriate referent for the second pronoun $\alpha$ v่ $\tilde{\nu}$ in Mt 21:7. First, a few textual emendations to the original Greek text are discussed, since the solution to the above problem has sometimes been sought in the discovery of a truly original text, free of this interpretative difficulty. Second, the grammatical and rhetorical explanations of the issue are elucidated. Third, the article presents and evaluates arguments for identifying the proper referent of $\alpha \dot{\tau} \tau \tilde{\omega} v$, whether in the vestments or in the two animals. In the author's opinion, the most convincing solution to the problem lies in identifying the referent of the ambiguous pronoun as the two animals.
\end{abstract}

Key WORDs: Mt 21:1-11, Mt 21:7, donkey, Jesus' entry narrative

\section{Wstęp: postawienie problemu}

W edług Mateuszowego opisu wjazdu Jezusa do Jerozolimy Jezus posyła dwóch uczniów do wsi Betfage, w której mają znaleźć przywiązaną oślicę (ővov) i będące razem z nią źrebię ( $\pi \tilde{\omega} \lambda \mathrm{ov})(21,2)$. Zgodnie z nakazem Jezusa dwaj uczniowie mają przyprowadzić dwoje zwierząt do Jezusa, gdyż, jak czytamy, „Pan ich ( $\alpha u ̛ \tau \tilde{\omega} v)$ potrzebuje” $(21,3)$. Polecenie to ma być wypełnieniem słów proroka cytowanego przez Mateusza (21,5), według którego król przybywa do Jerozolimy, siedząc na oślicy i na oślątku. Tekst grecki Mt 21,5,

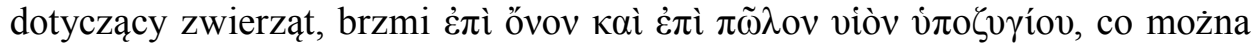
dosłownie przełożyć: „,na oślicy i na źrebaku, synu zwierzęcia pod jarzmem”.

1 Polskie tłumaczenia różnorodnie oddają tekst Mateusza: „na oślicy i na oślęciu, synu podjarzemnej” (Jakub Wujek); „,na osiołku, źrebięciu oślicy” (Biblia Tysiąclecia, 5 wyd.); „,na ośle, na 
Uczniowie wykonali polecenie Jezusa i przyprowadzili „oślicę i oślę” (

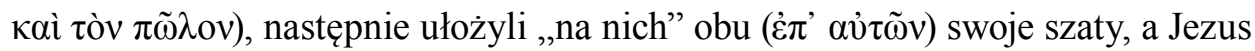

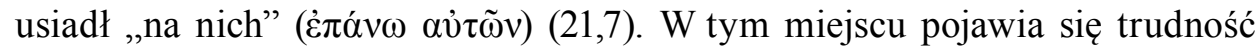

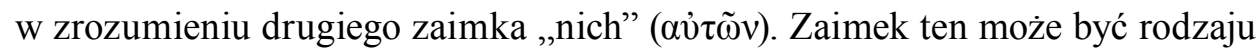
męskiego i odnosić się do zwierząt lub rodzaju nijakiego i odnosić się do szat. Współczesne przekłady w języku polskim doskonale oddają tę dwuznaczność tekstu greckiego ${ }^{2}$.

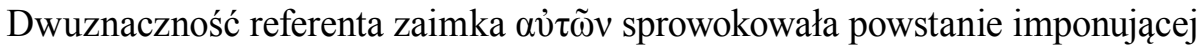
gamy wyjaśnień, datujących się od starożytności po czasy obecne. W efekcie można wyróżnić siedem różnych sposobów tłumaczenia trudności w identyfikacji referenta kontrowersyjnego zaimka $\alpha \grave{\tau o ̃ v . ~(1) ~ P i e r w s z e ~ w y j a s ́ n i e n i e ~ o p t u j e ~ z a ~ s z a-~}$ tami jako referentem. (2) Drugie wskazuje na parę osłów. (3) Kolejna propozycja interpretacyjna godzi dwa powyższe stanowiska stwierdzając, iż Mateusz miał na myśli zarówno szaty, jak i osły ${ }^{3}$. (4) Czwarte wyjaśnienie widzi w zapisie Mateusza zamierzoną dwuznaczność ${ }^{4}$. (5) Jeszcze inne ujęcie prezentują komentatorzy twierdzący, iż dwuznacznego zapisu Mateusza nie można racjonalnie wyjaśnić. Mateusz jest bowiem tak nieuważnym autorem, iż tego typu niejasności nie powinny dziwić. Nie należy zatem poświęcać nieprecyzyjnym zapisom specjalnej uwagi i zdać się na rozsądek w próbie wizualizacji i interpretacji Mateuszowych

oślęciu, młodym zwierzęciu jucznym” (Biblia Poznańska); „na ośle, na osiołku, który już nosi ciężary” (Biblia Paulistów); „dosiadający oślicy oraz oślęcia, źrebięcia będącej pod jarzmem” (R. Popowski, 2000); „na ośle, i na oślęciu, synu (bydlęcia) spod jarzma” (M. Wojciechowski, Grecko-polski Nowy Testament. Wydanie interlinearne z kodami gramatycznymi, 1994); ,na ośle, źrebięciu oślicy podjarzemnej” (Biblia Warszawska, Towarzystwo Biblijne w Polsce, 1975); „na oślicy, i na oślęciu, synu oślicy pod jarzmem będącej” (Biblia Gdańska); „na oślicy oraz na oślęciu, synu oślicy będącej pod jarzmem” (Nowa Biblia Gdańska); „na ośle, na oślątku, źrebięciu oślicy” (Uwspółcześniona Biblia Gdańska); „,na oślicy i na oślęciu tej, która jest pod jarzmem” (Biblia Brzeska); ,,na oślicy i na źrebięciu oślicy” (Biblia Warszawsko-Praska); ,na ośle, na źrebięciu jucznego zwierzęcia” (Nowe Przymierze, 2009).

2 „Nałożyli na nie płaszcze, a On usiadł na nie” (R. Popowski, 2000); ,nałożyli na nie szaty, i usiadł na nie" (M. Wojciechowski, Grecko-polski Nowy Testament. Wydanie interlinearne z kodami gramatycznymi, 1994); „włożyli na nie szaty swoje, i wsadzili go na nie” (Biblia Gdańska); „włożywszy na nie szaty swoje, usadzili go na nie” (Biblia Brzeska). Niektóre tłumaczenia przez użycie dwóch różnych zaimków, a mianowicie „nie” oraz „nich”, mogą sugerować, iż drugi zaimek nie odnosi się do zwierząt, ale do ubrań. Zob. „włożyli na nie odzienia swoje, a jego wsadzili na nie” (Jakub Wujek); ,położyli na nie swe płaszcze, a On usiadł na nich” (Biblia Tysiąclecia, 5 wyd.); ,położyli na nie swoje płaszcze. A On usiadł na nich” (Biblia Paulistów); ,„położyli na nich okrycia, a On usiadł na nich” (Biblia Poznańska); „włożyli na nie szaty, i posadzili go na nich” (Biblia Warszawska). Tłumaczenie Biblii Warszawsko-Praskiej usuwa trudność interpretacyjną: ,rozłożyli na nich swoje płaszcze, na których Jezus usiadl".

3 D.J. Harrington, The Gospel of Matthew (Sacra Pagina 1; Collegeville, MN: The Liturgical Press 1991) 293; R.T. France Matthew. An Introduction and Commentary (Downers Grove, IL: InterVarsity 1985) 302.

4 D. Instone-Brewer, „The Two Asses of Zechariah 9:9 in Matthew 21”, TynBul 54/1 (2003) 98. 
$\operatorname{scen}^{5}$. (6) W świetle kolejnego rozwiązania trudność interpretacyjna jest wynikiem emendacji tekstualnych. Oznacza to, iż obecnie znany nam tekst grecki, błędnie uchodzący za oryginalny, miałby być efektem poprawek naniesionych na jednoznaczny tekst oryginalny. (7) Ostatnią znaną nam możliwością poszukiwania rozwiązania trudności jest odwołanie się do zjawisk gramatycznych i retorycznych. Propozycje trzecia, czwarta, piąta i szósta nie zdobyły sobie szerokiego uznania wśród komentatorów. Zasadniczo rozwiązania te omijają trudność, czy to negując jej istnienie (stanowiska trzecie, czwarte i szóste), czy też uważając, iż jest ona nierozwiązywalna (piąte stanowisko). W poniższym artykule skupimy się zatem na ukazaniu i ocenie argumentów przemawiających za pozostałymi trzema rozwiązaniami (pierwszym, drugim i siódmym). Nieodzownym będzie także ustosunkowanie się do szóstej propozycji dotyczącej fundamentalnej kwestii tekstu oryginalnego.

Niniejszy artykuł otwiera dyskusja na temat emendacji tekstualnych występujących w interesujących nas wersetach perykopy Mt 21,1-11. Ma ona na celu ustalenie tekstu oryginalnego wersetów wzmiankujących parę osłów. Następnie zreferowano i oceniono rozwiązania trudności w identyfikacji referenta drugiego zaimka $\alpha \cup ̉ \tilde{\omega} v$ w 21,7 odwołujące się do gramatyki i retoryki. W kolejnych dwóch częściach artykułu przedstawione są i poddane krytycznej ocenie argumenty wysuwane za szatami i parą zwierząt jako referentami drugiego zaimka $\alpha u ̛ \tau \tilde{v} v$ w 21,7.

W prezentacji tytułowego problemu egzegetycznego będą nam przyświecały dwa cele. Pierwszym jest wskazanie najbardziej przekonującego rozwiązania trudności interpretacyjnej, uwiarygodnionego możliwie najbardziej wyczerpującą argumentacją. Drugi cel, historyczny ze swej natury, może być określony jako chęć prezentacji jak najszerszej gamy interpretacji trudności powstałych na przestrzeni wieków, a zatem nakreślenie wyczerpującego status quaestionis.

\section{Tekst oryginalny a hipoteza emendacji tekstualnych}

Niektórzy komentatorzy uważali, iż dwuznaczność Mt 21,7 jest wynikiem błędów powstałych w procesie transmisji tego tekstu. W opinii Alana H. McNeile’a zdanie

5 U. Luz, Matthew 21-28. A Commentary (Hermeneia - A Critical Commentary on the Bible; Minneapolis, MN: Fortress 2005) 8:,,[...] it is difficult to imagine Jesus' ride. With an author like Matthew who is frequently careless in concrete details, we should not even try to imagine it.” Luz cytuje również opinię, J. Duponta, który uważa, iż Mateusz „nie widzi” scen, które opisuje. Barnabas Lindars (New Testament Apologetic. The Doctrinal Significance of the Old Testament Quotations [London: SCM 1961] 114) nie znajduje żadnego wyjaśnienia dla dziwnego obrazu Jezusa jadącego na dwóch osłach i widzi tutaj zwyczajną nieuwagę Mateusza skutkującą problematycznym opisem: ,,[...] a mystery on any showing. Presumably it is confused writing rather than anything else". 


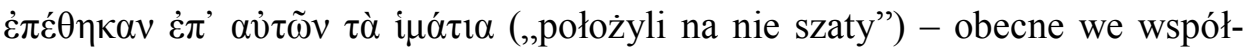
czesnych wydaniach krytycznych $\left(\mathrm{NA}^{28}, \mathrm{GNT}^{5}\right)$ - brzmiało w oryginale: $\dot{\varepsilon} \pi \dot{\varepsilon} \theta \eta \kappa \alpha \nu$

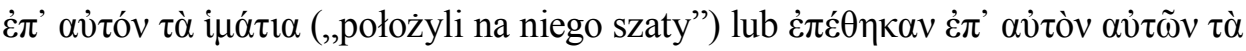

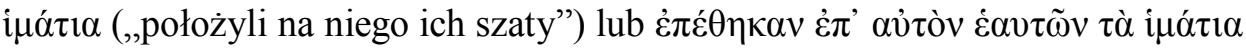
(,położyli na niego swoje własne szaty”) ${ }^{6}$. W tym samym duchu Theodor Zahn opowiada się za lekcją غ̇ं ${ }^{\prime}$ av̉ $\tau o ́ v$ jako oryginalną ${ }^{7}$. Sens tak zrekonstruowanego tekstu byłby następujący: uczniowie położyli swe szaty na jednym ośle, źrebięciu (jako ostatnim wzmiankowanym zwierzęciu w 21,7), a Jezus usiadł na szatach.

Powyższa propozycja lektury غ̇ं’ aủ óv nie jest nowatorskim pomysłem współczesnych egzegetów. Już w starożytności pojawiły się rękopisy greckie zmieniające w odniesieniu do osłów w naszej perykopie liczbę mnogą na liczbę

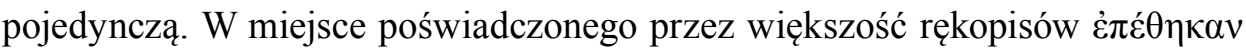

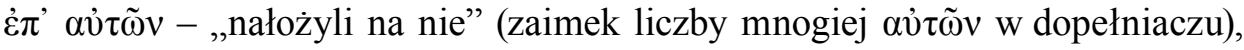
kilka rękopisów $\left(\Theta 1333124346788 \mathrm{f}^{13}\right)$ - najstarsze z nich $(\Theta$ 33) datowane są dopiero na IX w. - wstawiają zaimek rodzaju męskiego w celowniku (dati-

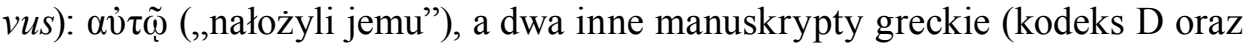
bizantyjski lekcjonarz 2211) używają zaimka rodzaju męskiego w bierniku (accusativus): aủ óv („nałożyli na niego”) ${ }^{8}$. Obie zmiany zaimka z liczby mno-

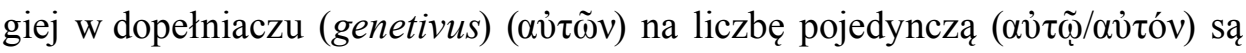

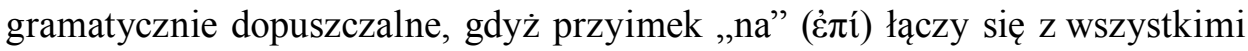
trzema wymienionymi przypadkami (genetivus, dativus, accusativus).

Szukając odpowiedzi na pytanie o oryginalność dwu lekcji z zaimkami av̉ī̄ oraz av̉ óv, można przedstawić kilka argumentów sugerujących wtórność tych wariantów. Po pierwsze, warianty te mogą być próbą ułatwienia lektury tekstu poprzez usunięcie trudnego do zrozumienia obrazu jazdy na dwóch osłach. Po

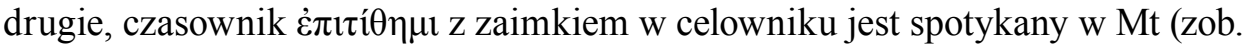

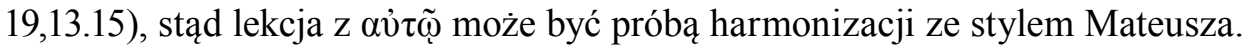
Po trzecie, obie lekcje mogą być wyjaśnione jako dążenie do harmonizacji tekstu Mateusza z tekstem Marka (11,7), w którym występują oba zaimki: „narzucili

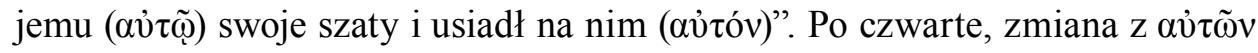
na $\alpha$ đóv może być też błędem ortograficznym, wynikającym z zastą̧ienia długiej samogłoski ( $\omega$ ) identycznie brzmiącą krótką samogłoską (o). Fakt, iż rękopisy poświadczające te lekcje są nieliczne oraz czasowo bardzo późne,

6 A.H. McNeile, The Gospel according to St. Matthew. The Greek Text with Introduction, Notes, and Indices (London: Macmillan 1915) 295.

7 T. Zahn, Das Evangelium des Matthäus (KNT 1; Helsingfors: Deichert'sche Verlagsbuchhandlung Nachf ${ }^{4}$ 1922) 690.

8 Zaimek liczby pojedynczej w bierniku poświadczony jest także w kilku rękopisach łacińskich (a b e f ff ${ }^{2}$ q). Najstarszy z nich (a) pochodzi z IV w. Najstarszy kodeks grecki (D) datowany jest na $\mathrm{V}$ w. Data pochodzenia rękopisów wskazuje, iż poprawki w tekście łacińskim nie bazowały na tekście greckim. 
argument piąty i szósty również przemawia przeciw uznaniu ich za warianty odzwierciedlające tekst oryginalny.

T. Zahn twierdzi, iż konstrukcja składająca się z czasownika غ̇ $\pi \imath i ́ \theta \eta \mu$ w połączeniu z غ̇ंí + genetivus, znajdująca się w Mt 21,7, jest niepoprawna. Poprawną konstrukcją jest czasownik غ̇ $\pi \imath i ́ \theta \eta \mu \mathrm{z}$ dativusem (zob. Mt 19,13.15) oraz czasownik غ̇ंı $i \hat{\theta} \eta \mu \mathrm{w}$ połączeniu z غ̇ंí + accusativus (zob. Mt 9,18; 23,4). Konkluzję tę, zdaniem niemieckiego egzegety, potwierdza częste zastępowanie

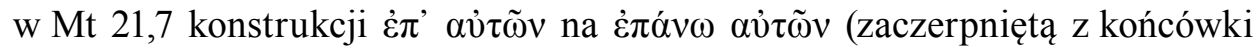

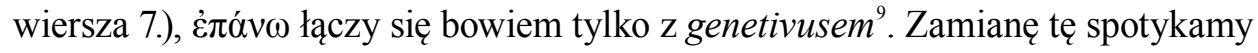
w C K N W Г $\Delta$ f $^{1} 565579700$ 892c $124114241844 \mathfrak{M}$ - najstarszym w tym katalogu jest kodeks C (Codex Ephraemi), datowany na V w. Teza T. Zahna nie wytrzymuje jednak próby dowodów, gdyż w samej Ewangelii Mateusza, poza

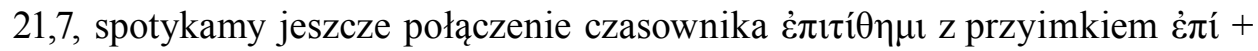

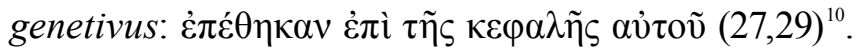

Wiele rękopisów greckich poświadcza także zmianę zaimka w kluczowym

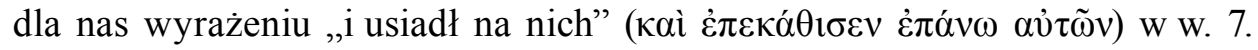
Korektor Kodeksu Synajskiego z IV w., żyjący w VI-VII w., oraz kopista tworzący Codex Regius (019, z VIII w.) poprawili zaimek $\alpha$ $\tau \tilde{\omega} v$ w liczbie mnogiej

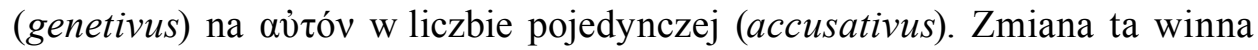

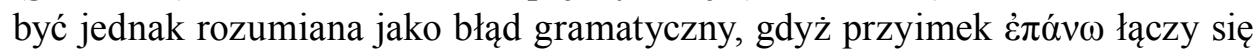
z dopełniaczem (genetivus). Gramatycznie poprawną jest zamiana $\alpha$ $\tau \tilde{\omega} v$ na

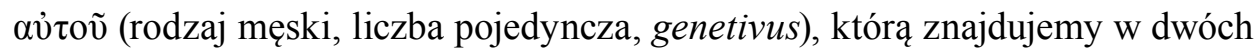
rękopisach greckich $(\mathrm{D} \Theta)^{11}$ oraz na $\alpha$ $\tau$ ท́ (rodzaj żeński, liczba pojedyncza, genetivus), której dokonał korektor żyjący w XI/XII w. w manuskrypcie minuskułowym z IX w. oznaczonym cyfrą 2 . W przypadku zmiany na $\alpha$ $\tau o \tilde{u}$ skryba

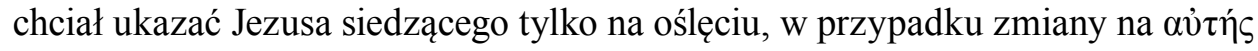
korektor ukazał Jezusa siedzącego na oślicy.

Inną próbą uczynienia tekstu bardziej zrozumiałym było opuszczenie kon-

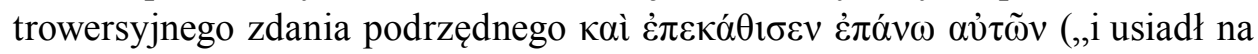
nie"). Tak skrócony tekst znajdujemy w dwóch kodeksach majuskułowych, Codex Basiliensis (VIII w.) i Codex Seidelianus I (IX w.), oraz w trzech rękopisach minuskułowych z wieków XI (2) oraz XII (1 oraz 2358). Niewielka liczba powyższych świadków oraz obecność tego zdania w podstawowych i starożytnych kodeksach czyni powyższą propozycję niewiarygodną.

Wartą odnotowania jest jeszcze jedna zmiana wprowadzana przez kopistów w tekście badanej perykopy. Część rękopisów ( $\Theta 579$ 1241) poświadcza

9 Zahn, Matthäus, 619.

10 G.M. Soares Prabhu, The Formula Quotations in the Infancy Narrative of Matthew. An Enquiry into the Tradition History of Mt 1-2 (AnBib 63; Rome: Biblical Institute Press 1976) 152-153.

11 Zmiana ta poświadczona jest także w kilku rękopisach łacińskich (b c e f ff ${ }^{2} h$ ). 
następujące zdanie: „A gdyby wam ktoś coś mówił, powiecie: «Pan go potrzebuje i zaraz je (l.mn.) odeśle»” (21,3). W miejsce liczby mnogiej ,ich potrzebu-

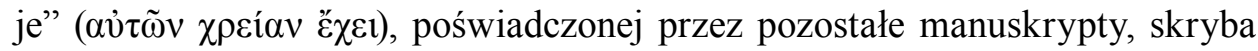

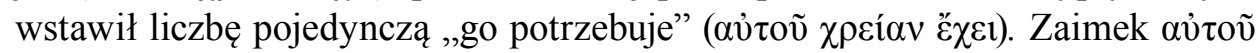
jest rodzaju męskiego i określa źrebię. Widać tutaj zatem chęć harmonizacji z pozostałymi Ewangeliami kanonicznymi, które mówią o dosiadaniu przez Jezusa jednego osiołka rodzaju męskiego. Tekst Marka $(11,3)$ jest identyczny

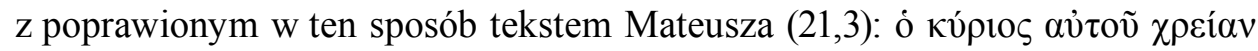

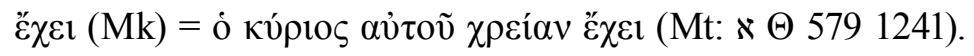

Powyższe emendacje tekstu greckiego poświadczone są przez niezwykle małą liczbę rękopisów. Jest to podstawowy argument za ich odrzuceniem jako pretendentów do bycia odzwierciedleniem tekstu oryginalnego. Odrzucenie tych wersji tekstualnych jako oryginalnych może być także wsparte przez dwa argumenty z krytyki wewnętrznej. Po pierwsze, zmiany te ułatwiają lekturę tekstu, usuwając problematyczny obraz Jezusa siedzącego na dwojgu zwierzętach ${ }^{12}$. Jak wiemy, jako oryginalny preferowany jest tekst trudniejszy. Po drugie, zmiany te można wyjaśnić próbą harmonizacji tekstu z opisami znajdującymi się w pozostałych trzech Ewangeliach kanonicznych.

\section{Wyjaśnienia gramatyczno-retoryczne}

W identyfikacji dwuznacznego referenta drugiego zaimka $\alpha$ niektórzy autorzy odwołują się figury retorycznej zwanej synekdochą, jeszcze inni - do figury zwanej enallage numeri $i^{13}$. Juan Maldonatus wskazuje jeszcze inną figurę retoryczną, a mianowicie syllepsę, czyli brak odpowiedniości między logiczną a gramatyczną budową wypowiedzi ${ }^{14}$. Wilhelm de Wette mówi jeszcze o dwóch możliwościach gramatycznych - nieokreślonej liczbie mnogiej

12 Tak oceniają dwie poprawki w Codex Bezae z liczby mnogiej na liczbę pojedynczą w Mt 21,7 dwaj krytycy tekstualni: M.W. Holmes, „Codex Bezae as a Recension of the Gospels”, Codex Bezae. Studies from the Lunel Colloquium, June 1994 (red. D.C. Parker - C.-B. Amphoux) (NTTS 22; Leiden: Brill 1996) 129; S.R. Pickering, „Readings of Codex Bezae in the Gospel of Matthew", NTTRU 4 (1996) 65-66.

13 I. Knabenbauer, Commentarius in Quatuor S. Evangelia Domini N. Jesu Christi. I/2. Evangelium secundum S. Matthaeum (Parisiis: Lethielleux 1893) 203; D. Whitby, „A Commentary on the Gospels and Epistles of the New Testament", A Critical Commentary and Paraphrase on the Old and New Testament and the Apocrypha (London: Thomas Tegg 1842) IV, 146; A. Martini, La Sacra Bibbia secondo la Vulgata tradotta in lingua italiana (Napoli: Gaetano Nobile 1844) $\mathrm{V}, 83$.

14 J. Maldonatus, A Commentary on the Holy Gospels (London: John Hodges 1888) II, 194. Zdaniem hiszpańskiego jezuity syllepsis występuje również w stwierdzeniu o nałożeniu szat na oboje zwierząt, gdyż w rzeczywistości nałożono je tylko na źrebię. 


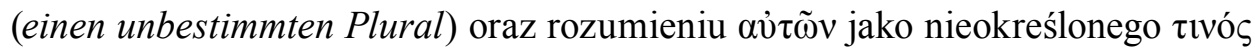
(„,czymś” $)^{15}$. Najbardziej przekonujące są dwie pierwsze propozycje: synekdocha oraz enallage numeri. W przypadku synekdochy ewangelista użyłby zasady totum pro parte, czyli mówiąc o dwu osłach (totum), na których Jezus miałaby siedzieć, miałby $\mathrm{w}$ istocie na myśli tylko jednego $\mathrm{z}$ nich (parte). W przypadku figury retorycznej zwanej enallage numeri ewangelista użył zaimka liczby mnogiej zamiast poprawnego w tym miejscu zaimka liczby pojedynczej. Komentatorzy przytaczają przykłady użycia tych dwóch figur retorycznych w tekstach biblijnych: Arka Noego zatrzymała się na górach Ararat (Rdz 8,4), choć w istocie chodziło o jedną górę, na której spoczęła; Lot miał mieszkać w zniszczonych miastach $(19,29)$, choć w rzeczywistości mieszkał tylko w jednym z nich; Abraham otrzymuje propozycję pochowania Sary w grobach, choć siłą rzeczy ma być pochowana tylko w jednym z nich $(23,6)$; wszyscy synowie Izraela popełnili grzech (Joz 7,1), choć w istocie dopuścił się go tylko Akan. Przykład synekdochy, czy też enallage numeri, znajdziemy także w Mt 27,44, gdzie mowa jest w liczbie mnogiej o złoczyńcach szydzących z Jezusa, choć w istocie robił to tylko jeden z nich. Ostatni przykład Max Zerwick kwalifikuje jako czysto gramatyczną kategorię zwaną pluralis categoriae: opisuje się w liczbie mnogiej przedmiot, który w rzeczywistości występuje w liczbie pojedynczej. Wskazuje się zatem na klasę, kategorię osób (złoczyńcy), zamiast na indywiduum (złoczyńca) ${ }^{16}$. Zdaniem wielu autorów casus zaimka av̉ $\tilde{\omega} v$ w Mt 21,7 także winien być wyjaśniany jako przykład pluralis categoriae ${ }^{17}$. Jak słusznie jednak zauważa George M. Soares Prabhu, pluralis categoriae mówi o jednostce w terminach jej przynależności do klasy. Innymi słowy, opisuje się tę jednostkę przez liczbowo nieokreśloną klasę. Nigdy jednak pluralis categoriae nie odnosi się do określonej liczbowo mnogości pojedynczych elementów, czego przykładem jest interesujący nas wiersz. W Mt 21,7 nie ma bowiem mowy o pojedynczym zwierzęciu czy nawet o dwojgu zwierzętach określonych poprzez przynależność do klasy. Istnieje natomiast odniesienie do precyzyjnej liczby dwóch wzmiankowanych wcześniej

15 W.M.L. de Wette, Kurze Erklärung des Evangeliums Matthäi (Kurzgefasstes exegetisches Handbuch zum Neuen Testament. I/1; Leipzig: Weidmannsche Buchhandlung 1838) 195.

16 M. Zerwick, Biblical Greek Illustrated by Examples (Scripta Pontificii Instituti Biblici; Roma: Editrice Pontificio Istituto Biblico 2001) §7. Inne przykłady wskazywane przez komentatorów: Mt 2,20.23; 14,9; 22,24; 24,26; Mk 4,10; 6,26; 7,37; Łk 5,21; 8,39; J 6,14.26; 8,24; 9,3.16.34; 10,21; 13,4. Jak zauważył Soares Prabhu (The Formula Quotations, 151), nie wszystkie powyższe sigle są właściwe. Dla przykładu, Mt 2,20 jest raczej aluzją do Wj 4,19, niż pluralis categoriae. Mt 2,23, wzmiankujące proroków, nie mówi, jak chcą komentatorzy, o Ozeaszu (cytowanym w 2,15), ale o prorokach w ogólności lub nawet o całym ST w jego prorockim aspekcie. Mt 24,26 to przykład nieokreślonej liczby mnogiej, a nie pluralis categoriae.

17 N. Turner, A Grammar of New Testament Greek J.H. Moulton. III. Syntax (Edinburgh: T\&T Clark 1963) 26; D.A. Carson, „Matthew”, The Expositor's Bible Commentary. VIII. Matthew, Mark, Luke (red. F.E. Gaebelein) (Grand Rapids, MI: Zondervan 1984) 438. 
w tekście zwierząt. Podsumowując, kategorie retoryczne mogą być pomocne w zrozumieniu tego tekstu. Zasada gramatyczna pluralis categoriae nie ma jednak zastosowania.

\section{Szaty jako referent drugiego zaimka aútw̃v w Mt 21,7}

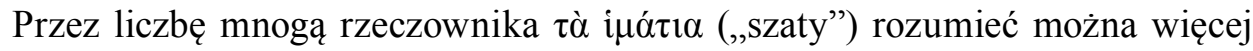
niż jedną szatę na grzbiecie każdego z dwojga zwierząt. Można sobie wyobrazić także sytuację, w której dwóch uczniów posłanych po zwierzęta nakłada na nie swoje szaty. W tym przypadku każde ze zwierząt miałoby na swym grzbiecie jedną szatę, a ostatni zaimek $\alpha$ ṽõ̃ w 21,7, odniesiony do szat w liczbie mnogiej, sugerowałby, iż Jezus usiadł na dwojgu zwierzętach. Jeśli zatem rozważamy tutaj casus szat jako referenta ostatniego zaimka $\alpha \hat{\tau} \tau \tilde{v} v$ w 21,7, mówimy o sytuacji, w której Jezus usiadł na wielu szatach na jednym ośle, mimo iż szaty (czy też jedna szata) były położone także na drugim ośle.

Można przytoczyć kilka argumentów, które sprawiły, iż wiele tłumaczeń i zdecydowana większość komentarzy, poczynając od Teofilakta z Ochrydy (zm. 1107; Enarratio in Evangelium Matthaei 21,7; PG 123,269) i Eutymiusza Zigabenosa (zm. 1116; Comm. in Matt.: PG 129,552), opowiada się za tłumaczeniem i wyjaśnieniem tekstu, w świetle którego Jezus miałby usiąść na szatach jednego ze zwierzą ${ }^{18}$. Po pierwsze, doświadczenie życia codziennego, w którym z zasady dosiada się jedynie jednego zwierzęcia wierzchowego, sugeruje, że Jezus raczej usiadł na szatach, a nie na dwojgu zwierzętach jednocześnie. Zauważmy, iż Mateusz żyje w kulturze, w której jeżdżenie na ośle było codziennością, wie on zatem więcej na ten temat niż współczesny egzegeta NT. Nie bez zdziwienia można odnaleźć jednak komentatorów twierdzących, iż jazda na

18 Za interpretacją tą opowiadają się Bruno z Segni (zm. 1123; PL 165,243), Aphonsus Tostatus (Abulensis) (zm. 1445), Cornelius Jansenius (zm. 1576), Juan Maldonatus (zm. 1583), Augustin Calmet (zm. 1757) i wielu późniejszych komentatorów. Współcześnie jest to dominujące wyjaśnienie referenta drugiego zaimka $\alpha \dot{\tau} \tau \tilde{\omega} v$ w Mt 21,7. Zob. B.T. Vivano, „The Gospel according to Matthew", The New Jerome Biblical Commentary (red. R.E. Brown - J.A. Fitzmyer R.E. Murphy) (Englewood Cliffs, NJ: Prentice Hall 1990) 664; R.T. France, The Gospel of Matthew (NICNT; Grand Rapids, MI - Cambridge, U.K.: Eerdmans 2007) 772: „They brought the donkey and the foal, and put cloths on them for Jesus to sit on". W jednym z polskich komentarzy (K. Romaniuk - A. Jankowski - L. Stachowiak, Komentarz praktyczny do Nowego Testamentu [Poznań: Pallottinum - Kraków: Tyniec. Wydawnictwo Benedyktynów 1999] I, 123), padają następujące stwierdzenia: ,,[...] wyrażenie: a On usiadt na nich, stanowi już tylko pozorną trudność. Wprawdzie biorąc pod uwagę reguły gramatyczne, zwrot na nich można odnieść do oślicy i do oślęcia, jednakże te same reguły oraz kontekst każą się domyślać, że chodzi raczej o szaty, na których usadowiono Jezusa". Komentatorzy niestety nie precyzują, jakie reguły gramatyczne i kontekst prowadzą do domysłu, iż zaimek odnosi się do szat. 
dwojgu zwierzętach jest ze wszech miar naturalna ${ }^{19}$. Po drugie, każda z trzech pozostałych Ewangelii kanonicznych wyraźnie mówi o dosiadaniu przez Jezusa w czasie wjazdu do Jerozolimy jednego zwierzęcia (Mk 11,7; Łk 19,35; J 12,1415). Zaimek w liczbie mnogiej winien odnosić się zatem nie tyle do osłów (gdyż, jak informują pozostałe Ewangelie kanoniczne, był tylko jeden osioł, na którym siedział Jezus), ile do szat. Po trzecie, najbliższą częścią zdania, do

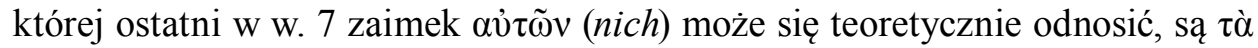

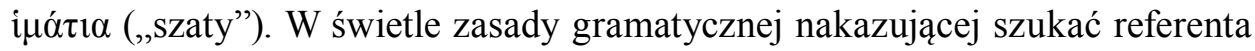
położonego jak najbliżej w tym samym zdaniu, szaty są najbardziej prawdopodobnym rozwiązaniem ${ }^{20}$. Po czwarte, nałożenie szat służyło temu, aby Jezus na nich usiadł. Konsekwentnie zatem, jeśli bezpośrednio po wzmiankowaniu nałożenia szat opisywana jest czynność siadania, to przedmiotem, na którym Jezus miał usiąść, winny być właśnie szaty ${ }^{21}$. Logice tego argumentu sprzeciwia się paralelne zdanie w Mk 11,7, gdzie mimo wzmiankowania nałożenia szat, ostatni zaimek odnosi się do siadania na osła, a nie na szaty. Po piąte, zmiana

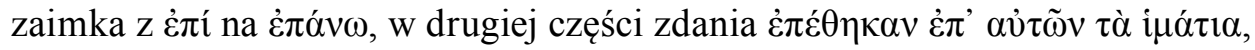

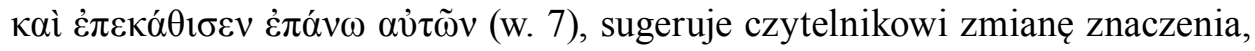
a mianowicie zmianę referenta drugiego zaimka $\alpha \grave{\tau} \tau \tilde{\omega} v \mathrm{w}$ stosunku do referenta pierwszego takiego zaimka występującego w tym zdaniu ${ }^{22}$. Po szóste, zdaniem

19 Dla przykładu Remigiusz, mnich z Auxerre, ok. 880 r. Zob. Thomas Aquinas, Catena Aurea. Commentary on the Four Gospels Collected out of the Works of the Fathers. I. St. Matthew (red. J.H. Newman) (Oxford: John Henry Parker 1841) 706.

20 C. Blomberg, Matthew (NAB 22; Nashville: Broadman \& Holman Publishers 1992) 313. Zob. także H. Fowler, The Gospel of Matthew (BSTS; Joplin, MO: College Press 1985) 31: „The pronoun's antecedent is normally the noun which is mentioned closest in the near context, unless other reasons prevail".

21 B.M. Newman - P.C. Stine, A Handbook on the Gospel of Matthew (New York, NY: United Bible Societies 1992) 640-641.

22 A. Plummer, An Exegetical Commentary on the Gospel according to St. Matthew (London: Robert Scott 1909) 286; R.H. Gundry, Commentary on the New Testament. Verse-by-Verse Explanation with a Literal Translation (Peabody, MA: Hendrickson Publishers 2010) 90. Alfred Plummer stwierdza, iż nie ma przykładu użycia przyimka ėđó $v \omega \mathrm{w}$ odniesieniu do jeżdżenia na zwierzęciu. Wychodząc z założenia, że przyimek ten oznacza „na szczycie, na wierzchu”, Plummer twierdzi, że byłoby nienaturalnym mówienie o jeżdżeniu „na szczycie” zwierzęcia. Podobny argument przedstawia Zahn (Matthäus, 619), twierdząc, że przyimek غ̇ $\pi \alpha ́ v \omega$ oznacza „nad” i wyraża jedynie siedzenie „nad” czymś, stąd nie może być użyty do opisu czynności jeżdżenia „na” zwierzęciu. Konsekwentnie, Jezus siedział „nad” ubraniami, ale nie „na” zwierzętach. Okazuje się jednak, iż argumentacja Plummera i Zahna jest chybiona. Po pierwsze,

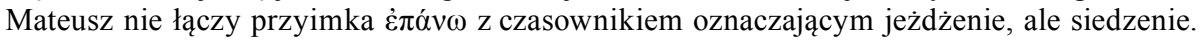
Nadto, czasownik wyrażający siedzenie na zwierzęciu wierzchowym w połączeniu z tym

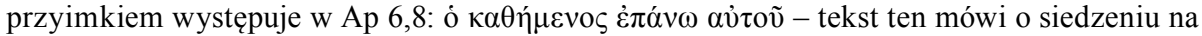
koniu. Połączenie tego przyimka z rzeczownikiem oznaczającym zwierzę spotykamy w Sdz 1,14

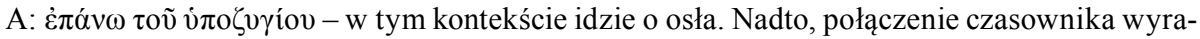

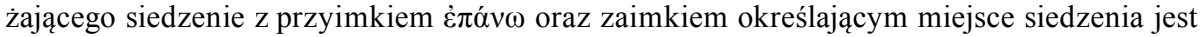
spotykane na innych miejscach Ewangelii Mateusza (zob. 23,22; 28,2). Zob. Fowler, Matthew, 31. 
Urbana Holzmeistera szaty są preferowane jako referent, gdyż tworzą aluzję do sposobu, w jaki król Jehu został uhonorowany przez przyjaciół w czasie swego wjazdu do Jerozolimy ( $2 \mathrm{Krl} 9,13)^{23}$. Argument ten nie jest przekonujący, gdyż $2 \mathrm{Krl}$ 9,13 mówi o słaniu szat przed stopami króla, jednak nie wspomina o czynności siadania króla na szatach. Po siódme, Wayne Coppins sugeruje, iż skoro tylko jedno zwierzę (oślica) było uwiązane (Mt 21,2), to tylko ono było przeznaczone do siedzenia ${ }^{24}$. Argument ten może być osłabiony przez przypuszczenie, iż także źrebię mogło być przywiązane. Nadto Jezus mógł jechać tylko na źrebięciu, choć tekst mówi jedynie o przywiązaniu oślicy ${ }^{25}$.

Powyższe przesłanki mają swoją mniejszą lub większą wartość argumentacyjną w uznaniu, iż ostatni zaimek $\alpha$ $v \tilde{\omega} v$ odnosi się do szat, a nie dwu osłów. W kolejnej części artykułu przedstawimy jednak również argumenty sugerujące prawdziwość odwrotnej tezy, a mianowicie takiej, w której to Jezus usiadł na osłach.

\section{Osły jako referent drugiego zaimka aủiw̃v w Mt 21,7}

We współczesnej literaturze egzegetycznej wskazywanych jest przynajmniej

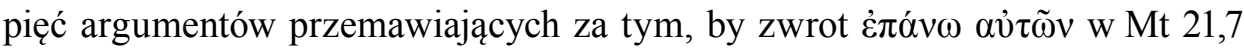
odnieść do zwierząt, a nie do szat. Argumenty zostaną przedstawione w kolejności odzwierciedlającej ich wartość merytoryczną, poczynając od mniej przekonujących i kończąc na najbardziej sugestywnych.

Po pierwsze, ewangelista wyraźnie mówi o nałożeniu szat na dwoje zwierząt. Skoro położono szaty na dwa osły, logiczną jest konkluzja o przeznaczeniu do jazdy obojga zwierzą ${ }^{26}$. Argument ten można jednak łatwo podważyć, przyjmując, iż szaty nałożono na osły w celach bardziej dekoracyjnych, niż praktycznych (zastąpienie siodła), aby podkreślić w ten sposób uroczysty charakter wjazdu Jezusa do Jerozolimy ${ }^{27}$. Jak słusznie zauważa Robert H. Gundry, nawet

23 U. Holzmeister, „De «plurali categoriae» in Nuovo Testamento et a patribus abhibito”, Bib 13 (1933) 75. Por. J. Nolland, The Gospel of Matthew. A Commentary on the Greek Text (NIGTC; Grand Rapids, MI - Cambridge, U.K.: Eerdmans 2005) 836.

24 W. Coppins, ,Sitting on Two Asses? Second Thoughts on the Two-Animal Interpretation of Matthew 21:7", TynB 63.2 (2012) 286, przypis 29: ,the fact that only one of the animals is explicitly said to be tied in Matt. 21:2, which could be taken as an analogy for the thesis that Jesus is only assumed to be sitting on one animal in Matt. 21:7".

25 Coppins, „Sitting on Two Asses?”, 283, przypis 23.

26 A. Loisy, Les Évangiles synoptiques (Ceffonds près Montier-en-Der [Haute-Marne]: chez l'auteur 1907-1908) II, 263; W.C. Allen, A Critical and Exegetical Commentary on the Gospel according to S. Matthew (ICC; Edinburgh: T. \& T. Clark $\left.{ }^{3} 1912\right) 220$.

27 France, Matthew (1985), 302; France, Matthew (2007), 778: „the festive occasion required that the mother, even though not ridden, should also be given a saddle cloth". 
we współczesnej Palestynie kładzie się okrycia zarówno na grzbiet oślicy, jak i idącego za nią nieujeżdżonego źrebięcia. Jest to powszechna praktyka, służąca udomowieniu młodego zwierzęcia ${ }^{28}$.

Po drugie, poczynając od Justyna (II w. po Chr., Dialogus cum Tryphone 53,1), istnieje nieprzerwana linia interpretacji wśród starożytnych autorów - także tych posługujących się językiem greckim - utrzymująca, iż Mateusz opisał wjazd Jezusa na dwóch osłach jednocześnie. W średniowiecznej sztuce sakralnej nie brak przedstawień, na których Jezus zmierza do Jerozolimy, siedząc okrakiem na grzbiecie oślicy, podczas gdy młode źrebię idzie pod oślicą, czy też tuż obok niej, tworząc obraz Jezusa siedzącego na grzbietach dwojga zwierząt.

Po trzecie, w bezpośrednim kontekście literackim obecne są trzy jednoznaczne odniesienia do dwojga zwierząt (21,2.3.7a). Fakt ten sprawia, iż czytelnik spontanicznie odnosi ostatni zaimek w w. 7 do osłów ${ }^{29}$.

Po czwarte, jeśli proroctwo Za 9,9 cytowane w Mt 21,5 ma odpowiadać opisywanemu przez ewangelistę wydarzeniu - a jak wynika z 21,4 taki jest cel cytatu - to miejsce, na którym Jezus siedzi w bezpośrednim kontekście $(21,7)$, winno być tożsame z miejscem siedzenia mesjańskiego króla w cytacie. Skoro zatem w cytacie mesjański król siedzi na dwojgu zwierzętach, to również w odpowiadającym mu wydarzeniu z udziałem Jezusa akcent winien spoczywać na fakcie siedzenia na zwierzętach, a nie na $\operatorname{szatach}^{30}$. Argument ten ma rację bytu, jeśli uznamy, iż Za 9,9, cytowany w Mt 21,5, nie jest paralelizmem synonimicznym mówiącym o jednym ośle. Kwestię widzenia w Za 9,9 jednego lub dwojga zwierząt rozwiniemy w odrębnym studium, które będzie stanowiło

28 R.H. Gundry, Matthew. A Commentary on His Literary and Theological Art (Grand Rapids, MI: Eerdmans 1982) 410. Nakładając szaty na oboje zwierząt, dano także Jezusowi - jak twierdzą inni komentatorzy, Eutymiusz Zigabenos (PG 129,552) czy H.A.W. Meyer (Kritisch Exegetischer Kommentar über das Neue Testament [Göttingen: Vandenhoeck und Ruprecht $\left.{ }^{4} 1858\right]$ 388) - możliwość wyboru zwierzęcia, którym chciał jechać, uczniowie bowiem nie wiedzieli, którego zwierzęcia Jezus chciał dosiąść. Wykładowcy prestiżowej École Biblique w Jerozolimie, Antonin Jaussen oraz Raphaël Savignac (Mission archéologique en Arabie. II. El-'Ela, d'Hégra à Teima, Harrah de Tebouk. Texte [Paris: Librairie Paul Geuthner 1914] 109) sugerowali, iż szaty nałożono na oboje zwierząt na ewentualność zastąpienia jednego krnąbrnego zwierzęcia przez drugie, bardziej skore do współpracy. Pojawiła się również mało przekonująca propozycja (H. Schanz, Commentar über das Evangelium des heligen Matthäus [Freiburg im Breisgau: Herder 1879] 434) twierdząca, że drugie zwierzę było przygotowane dla jednego z uczniów Jezusa, który miałby towarzyszyć Mistrzowi we wjeździe.

29 Luz, Matthew, 8: „because of the context the readers will first think of the animals”.

30 Coppins, „Sitting on Two Asses?”, 285: „once it is seen that the citation of Zechariah 9:9 in Matthew 21:5 looks forward to the two animals of 21:7, it is a very small step to conclude that it also looks forward to Matthew's talk of Jesus sitting on two animals in 21:7. In other words, since Matthew 21:5 speaks of the king being 'mounted on an ass and on a colt', which Matthew interprets as two animals, and since Matthew is evidently concerned to underscore that Jesus precisely fulfils this Scriptures, it follows that 21:7 very likely presents Jesus as siting on two animals". 
drugą część obecnego artykułu. W tym miejscu warto jednak przywołać, poza kontekstem Mateuszowym (zob. poprzedni, trzeci argument) dwa kolejne fakty wskazujące na rozumienie Za 9,9 jako mówiącego o dwojgu zwierzętach. Po

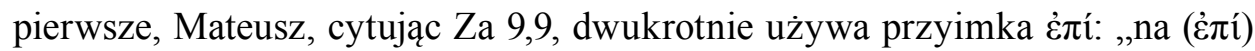
oślicy i na (غ̇лí) źrebaku, synu zwierzęcia pod jarzmem" $(21,5)$, co podkreśla istnienie dwojga zwierząt, na których siedział Jezus ${ }^{31}$. Rozumienie cytatu z Za 9,9 jako mówiącego o dwojgu zwierzętach może być również potwierdzone przez starożytne tłumaczenie greckie tego tekstu przypisywane Teodocjonowi: $\dot{\varepsilon} \pi \dot{~}$ övov kaì $\pi \tilde{\omega} \lambda$ ov viòv ővov, „na oślicy i na źrebięciu synu oślicy” ${ }^{32}$. Rzeczownik ővo może być rodzaju żeńskiego lub męskiego. Niezaprzeczalnie żeński rodzaj rzeczownika ővo $\mathrm{w}$ drugim członie sugeruje także żeński rodzaj w pierwszym członie. Gdyby bowiem Teodocjon chciał wskazać na męską płeć zwierzęcia w pierwszym członie, użyłby terminu innego niż rzeczownik ővo $̧$ zastosowany w drugim członie na określenie oślicy.

Po piąte, porównanie struktury zdania Mt z paralelnym zdaniem w Mk su-

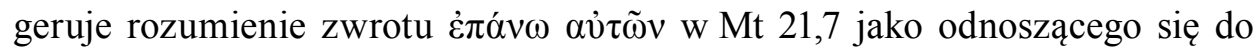
zwierząt, a nie do szat:

\section{Mk 11,7}

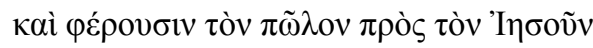

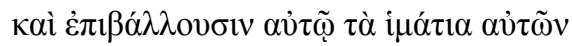

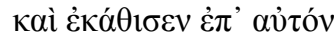

„Przyprowadzili więc oślę do Jezusa i zarzucili na nie (l.p.) swoje ubrania i usiadł na nim".

\section{Mt 21,7}

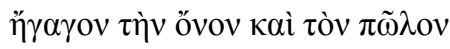

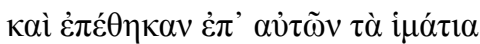

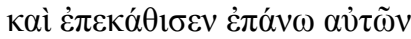

„Poprowadzili oślice i ośle i nałożyli na nie (1.mn.) ubrania i usiadł na nich".

Zarówno w Mk, jak i w Mt zdanie zbudowane jest z trzech członów o tym samym znaczeniu i następujących po sobie w tej samej kolejności:

31 Liczne rękopisy greckie, jednak bardzo późne (najstarsze to Codex Ephraemi oraz Codex Bezae z V w.) nie mają drugiego przyimka. Tekst oryginalny, poświadczony przez Codex Sinaiticus oraz Codex Vaticanus z IV w., zawierał zatem oba przyimki. Opuszczenie przyimka może być spowodowane wpływem tekstu LXX Za 9,9, gdzie występuje tylko jeden przyimek غ̇ $\pi i ́$. Zob. Coppins, „Sitting on Two Asses?”, 285: „there is every reason to think that Matthew cites this Scripture as speaking of $t w o$ animals, both because of the second $\dot{\varepsilon} \pi \dot{\text { and }}$ because verse 7 explicitly states that "they brought the ass and the cold and they placed the garments on them

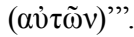

32 J. Ziegler (red.), Duodecim prophetae (Septuaginta. Vetus Testamentum Graecum 13; Göttingen: Vandenhoeck \& Ruprecht ${ }^{3}$ 1984) 310. 
(1) przyprowadzenie zwierzęcia/zwierząt: czasownik + rzeczownik, (2) nałożenie

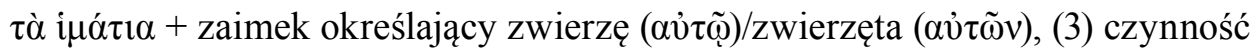
siedzenia. W obu przypadkach czasownik wyrażający czynność siedzenia łączy się z taką samą syntagmą: przyimek + zaimek, która określa miejsce, na którym Jezus siedział. W tekście Markowym Jezus usiadł „na nim” (zaimek av̉ óv w 1.p., r.m.), czyli na osiołku, gdyż szaty ( $\tau \alpha ̀$ i $\mu \alpha ́ \tau \iota \alpha)$ są w liczbie mnogiej i rodzaju nijakiego. W tekście Mateuszowym Jezus usiadł „na nich” (zaimek av̉ $\tilde{\omega} v, 1 . m n$.). Powyższe porównanie synoptyczne sugeruje, iż Mateuszowy zaimek w ostatnim trzecim członie należy odnieść do zwierząt.

Paralele w Łk 19,35 i J 12,14 mniej (w przypadku Łukasza) lub bardziej (w przypadku Jana) przekonująco sugerują rozumienie kontrowersyjnego Mateuszowego zaimka jako odnoszącego się do zwierząt.

\section{Łk 19,35}

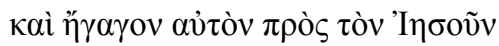

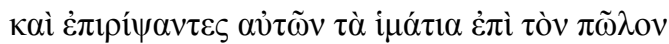

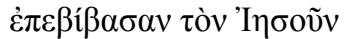

„Poprowadzili go do Jezusa

i narzuciwszy swoje szaty na oślę

posadzili Jezusa".

\section{J 12,14}

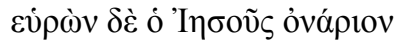

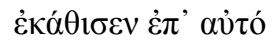

„Jezus zaś znalazłszy oślątko

$-$

usiadł na nim”.

W tekście Łukaszowym występuje ta sama trójczłonowa konstrukcja zdania, mająca generalnie to samo przesłanie semantyczne. W tekście Janowym natomiast, mimo braku drugiego członu, w ostatniej części występuje konstrukcja obecna zarówno w Mateuszu, jak i w Marku, a zatem czasownik opisujący czynność siedzenia łączący się z przyimkiem i zaimkiem określającym zwierzę.

Dodajmy, iż nie tylko paralela między opisem Marka 11,7 i Mateusza 21,7

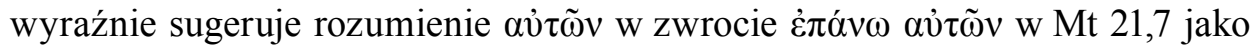
odnoszącego się do zwierząt. Otóż każde odniesienie do osła w liczbie pojedynczej w Markowym opisie wjazdu Jezusa do Jerozolimy zapisane jest w liczbie mnogiej w Mateuszowej wersji wjazdu:

Mk 11,2

„znajdziecie oślę uwiązane

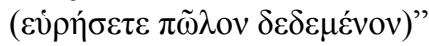

Mt 21,2

„znajdziecie oślicę uwiązaną

i oślę z nią

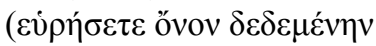

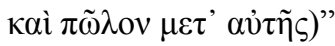


Mk 11,3

„Pan go potrzebuje

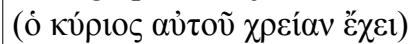

i natychmiast go pośle z powrotem tutaj

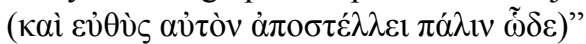

Mt 21,3

„Pan ich potrzebuje

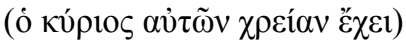

i natychmiast pośle ich

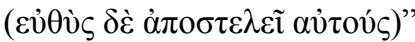

Jeśli zatem w Mt 21,7 napotykamy liczbę mnogą av̉ đ̃̃v z nieokreślonym referentem, a tekst Mk oferuje w miejscu paralelnym nawiązanie do osła w liczbie pojedynczej, na zasadzie zgodności Mt z pozostałymi Markowymi paralelami należy także w tym Mateuszowym tekście widzieć odniesienie do osłów.

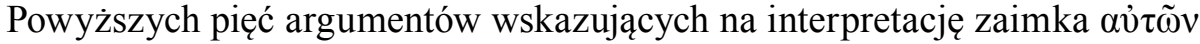

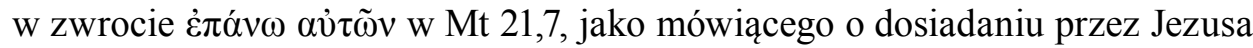
dwojga zwierząt, sugeruje teoretyczną możliwość, iż takie rozumienie tekstu było zamierzone przez samego ewangelistę. Argument pierwszy, mówiący o celowym nałożeniu szat na oboje zwierząt w celu użycia ich do jazdy, został powyżej podważony. Pozostałych argumentów nie można jednak zignorować. Uznanie, iż problematyczny zaimek odnosi się zarówno do zwierząt, jak i ubrań jednocześnie, rozwiązuje całą trudność, jednak nie bierze pod uwagę powyżej przedstawionych czterech ostatnich argumentów. W naszej opinii siła tychże argumentów każe nam przyjąć rozwiązanie, w którym referentem drugiego

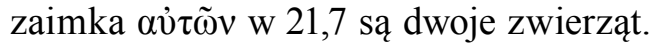

\section{Podsumowanie i wnioski}

Celem artykułu była krytyczna ewaluacja argumentów pozwalających zidentyfikować właściwy referent drugiego zaimka $\alpha$ $\tau \tilde{\omega} v \mathrm{w}$ Mt 21,7. W efekcie artykuł opisał, usystematyzował i w dużej części krytycznie ocenił całą gamę opinii dotyczących powyższego problemu. Polski czytelnik otrzymał w ten sposób wyczerpujące status quaestionis.

Pierwsza część artykułu opisuje sytuację tekstualną powiązaną z problemową kwestią. Okazuje się, iż tekst oryginalny w. 7, mówiąc o czynności

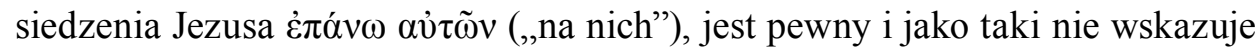
jednoznacznie referenta zaimka $\alpha$ $\tau \tilde{\omega} v$ („nich”). Pozostałe wersety perykopy wskazujące na obecność dwóch osłów w całym wydarzeniu uroczystego wjazdu Jezusa (w. 2.3.7) także nie budzą wątpliwości co do ich statusu jako tekstu oryginalnego. Omówione zmiany tekstualne służyły uczynieniu tekstu bardziej klarownym poprzez usunięcie problematycznej wizji siedzenia Jezusa na dwóch osłach oraz wyeliminowaniu obecności dwóch osłów w całym wydarzeniu uroczystego wjazdu, harmonizując opis Mateusza z pozostałymi Ewangeliami 
kanonicznymi. Krytyczna ocena świadków wykazała, iż tekst oryginalny jest pewny, mimo że kreuje większe trudności interpretacyjne.

W kolejnej części artykułu zaprezentowano gramatyczne i retoryczne rozwiązania trudności w identyfikacji właściwego referenta drugiego zaimka $\alpha$ $\tau \tilde{\omega} v$ w Mt 21,7. Rozwiązanie gramatyczne Maxa Zerwicka odwołujące się do pluralis categoriae nie jest przekonujące, w odróżnieniu od wyjaśnień retorycznych mających znamiona prawdopodobieństwa.

Kolejna część artykułu ukazała dwie zasadnicze propozycje identyfikujące referenta drugiego zaimka $\alpha \hat{\tau} \tilde{\omega} v$ w Mt 21,7. Mimo mocnych argumentów wskazujących szaty jako referenta, solidne przesłanki ma również identyfikacja osłów jako referenta kontrowersyjnego zaimka. $Z$ jednej strony, wobec wagi argumentów stojących za obydwiema identyfikacjami istnieje pokusa uznania tego tekstu za intencjonalnie dwuznacznego (D. Instone-Brewer), z drugiej zaś, niezwykle dokładne paralele z tekstem Marka oraz Mateuszowa emfaza na obecności dwojga zwierząt skłaniają do uznania za właściwego referenta parę zwierząt.

\section{Bibliografia}

Allen, W.C., A Critical and Exegetical Commentary on the Gospel according to S. Matthew (The International Critical Commentary; Edinburgh: T. \& T. Clark ${ }^{3} 1912$ ).

Blomberg, C., Matthew (New American Bible 22; Nashville: Broadman \& Holman Publishers 1992). Carson, D.A., „Matthew”, The Expositor's Bible Commentary. VIII. Matthew, Mark, Luke (red. F.E. Gaebelein) (Grand Rapids, MI: Zondervan 1984) 1-599.

Coppins, W., „Sitting on Two Asses? Second Thoughts on the Two-Animal Interpretation of Matthew 21:7", Tyndale Bulletin 63/2 (2012) 275-290.

Fowler, H., The Gospel of Matthew (Bible Study Textbooks Series; Joplin, MO: College Press 1985) I-IV.

France, R.T., Matthew. An Introduction and Commentary (Downers Grove, IL: InterVarsity 1985).

France, R.T., The Gospel of Matthew (The New International Commentary on the New Testament; Grand Rapids, MI - Cambridge, U.K.: Eerdmans 2007).

Gundry, R.H., Commentary on the New Testament. Verse-by-Verse Explanation with a Literal Translation (Peabody, MA: Hendrickson Publishers 2010).

Gundry, R.H., Matthew. A Commentary on His Literary and Theological Art (Grand Rapids, MI: Eerdmans 1982).

Harrington, D.J., The Gospel of Matthew (Sacra Pagina 1; Collegeville, MN: The Liturgical Press 1991). Holmes, M.W., „Codex Bezae as a Recension of the Gospels”, Codex Bezae. Studies from the Lunel Colloquium, June 1994 (red. D.C. Parker - C.-B. Amphoux) (New Testament Tools and Studies 22; Leiden: Brill 1996) 123-160.

Holzmeister, U., „De «plurali categoriae» in Nuovo Testamento et a patribus abhibito”, Biblica 13 (1933) 68-95. 
Instone-Brewer, D., „The Two Asses of Zechariah 9:9 in Matthew 21”, Tyndale Bulletin 54/1 (2003) 87-98.

Jaussen, A. - Savignac, R., Mission archéologique en Arabie. II. El-'Ela, d'Hégra à Teima, Harrah de Tebouk. Texte (Paris: Librairie Paul Geuthner 1914).

Knabenbauer, I., Commentarius in Quatuor S. Evangelia Domini N. Jesu Christi. I/2. Evangelium secundum S. Matthaeum (Parisiis: Lethielleux 1893).

Lindars, B., New Testament Apologetic. The Doctrinal Significance of the Old Testament Quotations (London: SCM 1961).

Loisy, A., Les Évangiles synoptiques (Ceffonds près Montier-en-Der [Haute-Marne]: chez l'auteur 1907-1908) I-II.

Luz, U., Matthew 21-28. A Commentary (Hermeneia - A Critical and Historical Commentary on the Bible; Minneapolis, MN: Fortress 2005).

Maldonatus, J., A Commentary on the Holy Gospels (London: John Hodges 1888).

Martini, A., La Sacra Bibbia secondo la Vulgata tradotta in lingua italiana (Napoli: Gaetano Nobile 1844).

McNeile, A.H., The Gospel according to St. Matthew. The Greek Text with Introduction, Notes, and Indices (London: Macmillan 1915).

Meyer, H.A.W., Kritisch exegetischer Kommentar über das Neue Testament (Göttingen: Vandenhoeck und Ruprecht ${ }^{4} 1858$ ).

Newman, B.M. - Stine, P.C., A Handbook on the Gospel of Matthew (New York, NY: United Bible Societies 1992).

Nolland, J., The Gospel of Matthew. A Commentary on the Greek Text (The New International Greek Testament Commentary; Grand Rapids, MI - Cambridge, U.K.: Eerdmans 2005).

Pickering, S.R., „Readings of Codex Bezae in the Gospel of Matthew”, New Testament Textual Research Update 4 (1996) 61-66.

Plummer, A., An Exegetical Commentary on the Gospel according to St. Matthew (London: Robert Scott 1909).

Romaniuk, K. - Jankowski, A. - Stachowiak, L., Komentarz praktyczny do Nowego Testamentu (Poznań: Pallottinum - Kraków: Tyniec. Wydawnictwo Benedyktynów 1999) I-II.

Schanz, H., Commentar über das Evangelium des heiligen Matthäus (Freiburg im Breisgau: Herder 1879).

Soares Prabhu, G.M., The Formula Quotations in the Infancy Narrative of Matthew. An Enquiry into the Tradition History of Mt 1-2 (Analecta Biblica 63; Rome: Biblical Institute Press 1976).

Thomas Aquinas, Catena Aurea. Commentary on the Four Gospels Collected out of the Works of the Fathers. I. St. Matthew (red. J.H. Newman) (Oxford: John Henry Parker 1841).

Turner, N., A Grammar of New Testament Greek J.H. Moulton. III. Syntax (Edinburgh: T\&T Clark 1963).

Vivano, B.T, „The Gospel according to Matthew”, The New Jerome Biblical Commentary (red. R.E. Brown - J.A. Fitzmyer - R.E. Murphy) (Englewood Cliffs, NJ: Prentice Hall 1990) 630-674.

Wette, W.M.L. de, Kurze Erklärung des Evangeliums Matthäi (Kurzgefasstes exegetisches Handbuch zum Neuen Testament. I/1; Leipzig: Weidmannsche Buchhandlung 1838).

Whitby, D., „A Commentary on the Gospels and Epistles of the New Testament”, A Critical Commentary and Paraphrase on the Old and New Testament and the Apocrypha (London: Thomas Tegg 1842) IV, 33-205.

Wojciechowski, M., Grecko-polski Nowy Testament. Wydanie interlinearne z kodami gramatycznymi (Prymasowska Seria Biblijna; Warszawa: Vocatio 1994). 
Zahn, T., Das Evangelium des Matthäus (Kommentar zum Neuen Testament 1; Helsingfors: A. Deichert'sche Verlagsbuchhandlung Nachf $\left.{ }^{4} 1922\right)$.

Zerwick, M., Biblical Greek Illustrated by Examples (Scripta Pontificii Instituti Biblici; Roma: Editrice Pontificio Istituto Biblico 2001).

Ziegler, J. (red.), Duodecim prophetae (Septuaginta. Vetus Testamentum Graecum 13; Göttingen: Vandenhoeck \& Ruprecht ${ }^{3} 1984$ ). 